\title{
The Impact of the Internationalisation of Multinational Banks on Non-financial Foreign Direct Investment in West Africa: A Modified Gravity Equation Approach
}

\author{
EI BekrI Hafsa \\ Euromed Business School, Euro-Mediterranean University of Fes, Morocco
}

Received November 7, 2019; Revised December 3, 2019; Accepted December 10, 2019

Copyright $\bigcirc 2020$ by authors, all rights reserved. Authors agree that this article remains permanently open access under the terms of the Creative Commons Attribution License 4.0 International License

\begin{abstract}
The paper is devoted to explore the impact of Moroccan banks on the increase of FDI in West African Countries. We estimate the determinants of foreign direct investment flows using the gravity equation, taking into account the importance of both the traditional gravity variables (size, distance) and the financial flows (loans granted by Moroccan banks in African countries). The purpose of this paper is to verify whether Multinational banks can constitute a gravitational force to attract the industrial firms towards host countries in South-South relations. The data used cover the period 2010-2015 and focuses on 5 African countries Benin, Burkina Faso, Côte d'Ivoire, Mali and Senegal. The gravity model is estimated in individual fixed-effect panel data by the ordinary least squares method. The results highlight that the internationalization of Moroccan Banks increased the volume of non-financial FDI from the same home-market (Morocco) in Western African Countries.
\end{abstract}

Keywords South-South Financial Flows, Moroccan Banks, African Countries, Non-financial FDI, Gravity Equation

JEL Code: C01, F21, F65

\section{Introduction}

In recent years, it has become apparent that South-South financial relations are increasing. According to the banking commission of the West African Economic and Monetary Union (UEMOA), in 2018 Moroccan banks have concentrated $27.8 \%$ of the market share in the WAEMU, and more than $30 \%$ of the share of the overall net profit in the region.

According to several authors, the multinationalization of banks is directly linked to the increasingly international activity of their industrial clients.

Several theatrical works provide evidence that the presence of foreign banks boosts foreign direct investment by non-financial firms (A. Alfaro et al, (2010) [1]).

A strong positive effect of banking FDI on non-financial FDI of the same origin country has been proven (Steven Poelhekke, 2014 [2]).

The aim of this study is to verify whether multinational banks can constitute a gravitational force to attract the industrial firms towards host countries in South-South relations. And verify the analogy between internationalization of banks and firms in those relations.

The data used cover the period 2010-2015 and focuses on 5 African countries Benin, Burkina Faso, Côte d'Ivoire, Mali and Senegal.

The gravity model is estimated in individual fixed-effect panel data by the ordinary least squares method.

The econometric method chosen allows taking account of the individual heterogeneity of the data set. As a result, a set of statistical tests will be conducted to determine the econometric model adapted to our model. These statistics will allow us to know whether we can admit individual heterogeneity via Fisher's tests; or deny the GLS estimator (least generalized squares) of the random effect model (via the Hausman test).

The paper is organized as follows. Section 2 reviews the related literature. Section 3 introduces the details of the empirical methodology. Section 4 provides the data and empirical results and Section 5 concludes the paper.

\section{Literature Review: Multinational Banks and Non-financial FDI}

To highlight the existence of a parallelism between industrial and banking multinationalization, (Joel Métais 
1979 [3]) analyzes the internationalization of American banks in the 1960s, and the growth of industrial FDI of US over the same period. The results of the study conclude to a positive correlation between the two phenomena. In fact, "while US direct investment rose from $\$ 52$ billion to $\$ 145$ billion between 1966 and 1977, the number of US banks overseas increased from 13 to 130 , with a branch network growing from 241738 , not to mention other forms of presence abroad. The author emphasizes that this attraction factor is valid regardless of the size of the bank.

A recent literature stresses the benefits of general financial development -which is partly driven by foreign banks- on non-financial FDI. In his paper "Do global banks facilitate foreign direct investment?" Steven (Poelhekke, 2014) studied the benefits of multinational banking to other international firms, motivated by the premise that countries benefit from FDI. This paper finds that banks' direct investment abroad increased the volume of non-financial FDI from the same home-market.

The banking literature has mostly focused on the implications of bank globalization for host countries (Goldberg, 2009 [4]). The main areas of investigation have been the efficiency of host-country banks, the financial sector technology spillovers, the political influence, the impact on growth. Home banking sector shocks also affect outward FDI directly: (Klein et al. 2002 [5]) show that firms initiate fewer FDI projects if their home bank is in distress. (Steven Poelhekke 2014) adds to this literature by investigating whether banking FDI increases the foreign investment opportunities of firms, and thereby increases non-financial FDI.

This paper aims to add to the literature by shifting the focus to the impact of multinational banking to other international firms in South-South relations.

\section{Methodology}

The origins of our empirical model - the FDI gravity model- lie in the physical theory of gravity. Newton's law of universal gravitation states that the gravitational attraction between two objects is proportional to the product of their masses and inversely proportional to the square of the distance between them.

In very simple form gravity approach to FDI suggests that FDI is positively related to GDP levels both in host and source countries and negatively related to the distance between them. The use of gravity model in explaining FDI flows is supported theoretically. The most well-known theoretical framework is Dunning's (1958) eclectic OLI (Ownership, Location, Internalization) paradigm.

The first version of the model was suggested by (Tinbergen 1962 and Pöyhönen 1963 [6]). They concluded that exports are positively affected by income of the trading countries and that the distance between the countries is likely to affect exports negatively. Lately there have been made a number of contributions to this early version.
A number of empirical studies, which analyze bilateral FDI flows through the framework of gravity model, have appeared also. (Frenkel, Funke, Stadtmann 2004 [7]) examined the determinants of FDI flows to emerging economies. They used OLS estimators for panel data of bilateral FDI flows from the selected developed countries to emerging economies to test the crude form of gravity model and its several specifications. In order to capture the home and the host countries effects and the time effects they used two-component model with dummy variables. They found that while market size and distance play an important role for FDI flows, other economic characteristics like risk and economic growth in host countries are also crucial for attracting international investment projects.

\subsection{The Model}

We propose to adapt this model in order to study the relationship between industrial FDI and financial flows out of Morocco to West African countries; with FDI flows as a response variable and financial flows (loans granted by Moroccan banks in Africa) as an explanatory variable.

In this gravity model of FDI we didn't include geographic distance but variable illustrating economic distance, namely: Absolute value of the difference of GDP between Morocco and host country.

Could Multinational Moroccan banks make non-financial foreign investment easier for firms from the same origin country?

To answer this question, we opt for the gravity model by estimating the following gravitational equation:

$\log ($ FDImjt $)=\alpha 0+\alpha 1 \log ($ FFmjt $)+\alpha 2 \log ($ GDPjt $)+$ $\alpha 3 \log ($ DGDPmjt $)+\mu \mathrm{mj}$

FDImjt represents the flow of FDI entering the country $j$ from Morocco $(\mathrm{m})$ at the date $\mathrm{t}$. In our study we are interested in industrial FDI flows from Morocco to WAEMU countries. The lack of bilateral data from industrial FDI forces us to use the total flow of Moroccan FDI to WAEMU countries, even though it includes the share of investments by Moroccan banks.

FFmjt: The financial flows variable represents loans granted by Moroccan banks located in WAEMU countries. A positive and significant coefficient of this variable would mean a support effect and financing of industrial investments from Morocco by Moroccan banks located in Africa. A positive sign of this coefficient is therefore expected.

GDPj: represents the GDP of the host country. The more the GDP of the country is important, the more FDI to that country would be important. In other words, the greater the internal economic dynamics of the country, the more Moroccan companies would be encouraged to internationalize. A positive sign of the coefficient of this variable is therefore expected.

DGDPTm $j$ is the difference in absolute value between 
the GDP per capita of Morocco $m$ and that of the country of implantation $\mathrm{j}$ at the date $\mathrm{t}$. The difference between the GDP per capita of the two partner countries expressed in absolute value $(D \mathrm{GDPT} \mathrm{m} j=|P I B \mathrm{~m}-P I B j|)$ is a measure of the economic distance between Morocco and the host countries. A high economic distance between Morocco and the WAEMU countries would have a negative impact on the evolution of Moroccan FDI.

Umj: is a stochastic error term.

\section{Data and Empirical Results}

The study focuses on five countries (Benin, Burkina Faso, Côte d'Ivoire, Mali, and Senegal). The choice of those countries is mainly justified by the availability of the data needed to analyze FDI and financial flows.

The data used cover the period 2010-2015 and are derived from:

- The BCEAO statistical database for loans granted by the three Moroccan banking groups (Attijariwafabank, BMCE and BCP) in the WAEMU countries; and

- The UNCTAD database for FDI flows between Morocco and the host countries.

The two main variables that will be the subject of the study are:

- Outward Foreign direct investment from Morocco to the WAEMU countries.

- Financial flows between Morocco and WAEMU countries.

The gravity model is estimated in individual fixed-effect panel data by the ordinary least squares method.

The estimation of our model was carried out on the software Eviews (eviews9).

After a first regression of the previous equation, we found a case of total heterogeneity of the model. (Added value of $F 2=0.0004)$. In order to overcome this problem, we thought it would be better to improve our model by introducing new explanatory variables: the tax pressure rate in the host countries; The Harmonized Index of Consumer Prices; Public investments in terms of infrastructure.

To better capture the influence of specific country characteristics, we added other variables namely:

FDImjt represents the flow of FDI entering the country $j$ from Morocco (m) at the date t. In our study we are interested in industrial FDI flows from Morocco to WAEMU countries. The lack of bilateral data from industrial FDI forces us to use the total flow of Moroccan FDI to WAEMU countries.

FFmjt: The financial flows variable represents loans granted by Moroccan banks located in WAEMU countries. A positive and significant coefficient of this variable would mean that outward FDI from Morocco are financed by Moroccan banks located in host countries. A positive sign of this coefficient is therefore expected.

GDPj: represents the economic growth rate of the host country given by the GDP growth rate. The larger the economic size of the country, the more FDI to that country would be important.

DGDPmj $\boldsymbol{t}$ is the difference in absolute value between the GDP per capita of Morocco $m$ and that of the country of implantation $\mathrm{j}$ at the date $t$. The difference between the GDP per capita of the two partner countries expressed in absolute value $(D P I B T \mathrm{~m} j=|P I B \mathrm{~m}-P I B j|)$ is a measure of the economic distance (growth differential) between Morocco and the countries where Moroccan banks are located. A high economic distance between Morocco and the WAEMU countries would have a negative impact on the evolution of Moroccan FDI.

PTaxjt is the tax rate estimated by the World Bank. This synthetic rate includes taxes on income, profits and capital gains collected on the real or estimated income of individuals, on profits of businesses and corporations, and on capital gains whether or not realized on land, securities or other assets. This variable indicates the impact of tax regulations in host countries on Moroccan investors. A low tax rate would have a positive impact on foreign investment.

IHPCjt: The Harmonized Index of Consumer Prices (HICI) is an indicator of macroeconomic stability. An increase in this index indicates a rise in the inflation rate, which could indicate an unstable macroeconomic framework and should discourage foreign investment. This variable is expected to have a negative sign.

DPUBjt: Public investments can contribute positively to the increase of FDI flows, especially when it reflects investing in infrastructure and increasing quality of public services.

TXINVESTjt: The investment rate (TXINVEST) (gross fixed capital formation relative to GDP): this rate reflects the economic dynamism of the host country. The expected impact of this variable is positive.

Umj: is a stochastic error term.

However, this estimate does not take into account the impact of political instability factors, particularly due to the lack of reliable data.

After performing the Hsiao test on the following gravitational equation:

$\log ($ IDEmjt $)=\alpha 0+\alpha 1 \log ($ FFmjt $)+\alpha 2 \log ($ GDPjt $)+$ $\alpha 3 \log ($ DGDPmjt $)+\alpha 4 \log ($ PFISCjt $)+\alpha 5 \log ($ IHCjt $)+$ $\alpha 6 \log ($ Dpub $)+\alpha 7 \log ($ txinv $)+\mu \mathrm{mj}$

It seems that the structure of this estimate is heterogeneous ( $\mathrm{F} 2=0.03<5 \%$ ).

We propose to use only four explanatory variables.

The gravitational equation will therefore be presented as follows:

$\log ($ FDImjt $)=\alpha 0+\alpha 1 \log ($ FFmjt $)+\alpha 2 \log ($ GDPjt $)+$ $\alpha 3 \log ($ DGDPmjt $)+\alpha 3 \log ($ IHCjt $)+\mu m j$

After removing some variables and reducing the number 
of individuals. The homogeneity tests (hsiao) showed that the panel has an individual effects structure. We will develop the results of the tests and estimation in the following paragraphs.

- List of hypotheses

We have developed four hypotheses in this econometric model.

H1: The evolution of financial flows has a positive impact on FDI.

$\mathrm{H} 2$ : The economic growth of the host countries has a positive impact on the evolution of FDI.

H3: A high economic distance between the country of origin and the host country has a positive impact on the evolution of FDI.

H4: A high consumer price index in host countries has a negative impact on FDI.

\section{- $\quad$ Empirical Tests}

The statistical tests we performed on the data showed us individual heterogeneity and rejected the hypothesis of independence between unobserved individual heterogeneity and explanatory variables. These tests are Fisher and Hausman tests. Therefore, we used a fixed individual effect model that we tested by ordinary least squares, first, to determine the estimated coefficients $\alpha 1, \beta$ $1, \beta 2, \beta 3, \beta 4$. Where $\alpha 1$ represents the constant and $\beta 1, \beta$ $2, \beta 3, \beta 4$ the coefficients attached to the explanatory variables.

Our model to estimate thus takes the following form:

$\log (\mathrm{IDE})=\alpha 1+\beta 1 \log (\mathrm{FF})+\beta 2 \log (\mathrm{GDP})+\beta 3 \log$ $($ Dist $)+\beta 4 \log (\mathrm{IHC})+\mathrm{Umj}$

The Hausman test statistic, for the sample studied, is equal to 45 . Since our model includes four explanatory variables $(\mathrm{K}=4)$, then this statistic follows a $\chi^{2}$ with four degrees of freedom. The probability given by the program is equal to 0 . Thus, we must reject the null hypothesis and we must favor the adoption of a model with fixed individual effects.

After showing the existence of individual effects and having demonstrated its nature "fixed", we can estimate the equation using the fixed individual effects model. The results of the estimation are presented in the table 1 (see appendix 1).

The model is globally significant since the $R^{2}$ is 0.84 . The model is significant at $84 \%$.

- Main results: Hypothesis Verification

- The impact of financial flows on FDI

We note that financial flows impact positively and significantly Moroccan FDI in African countries. An increase in financial flows of $1 \%$ leads to an increase in

\section{Moroccan FDI of $5.37 \%$.}

\section{- The impact of GDP on FDI}

There is a significant and positive relationship between host countries' economic growth and Morocco's FDI in these countries. An increase in economic growth of $1 \%$ in host countries leads to a decrease in FDI of $2.09 \%$ leaving Morocco to these countries.

\section{- The impact of economic distance on FDI}

There is a significant and negative relationship between the economic distance between Morocco and the host countries and FDI (at 5\% probability level). The distance between the countries is likely to affect FDI negatively. An increase in the economic distance of $1 \%$ leads to a decrease in FDI of $9.6 \%$.

- The impact of the harmonized index of prices on FDI An increase in this index indicates a rise in the inflation rate, which could indicate an unstable macroeconomic framework and should discourage foreign investment.

We find that the price index has a significant and negative impact (at 5\% probability level) on Moroccan FDI in African countries. An increase in the rate of the consumer price index of $1 \%$ leads to a decrease of FDI of $0.69 \%$.

\section{Conclusions}

The particularity of our study is to analyze the impact of the multinational banks on non-financial FDI from the same origin country in South-South relations.

Our findings highlight two main conclusions. The internalization of Moroccan banks boosts the non-financial FDI to their host countries. The gravity model has confirmed that the internationalization of Moroccan banks constitutes a gravitational force to attract industrial firms to their host countries. Therefore we can talk about a parallelism between banking internationalization and non-financial FDI in South-South relations (MoroccoWest Africa).

\section{Acronyms}

FDI: Foreign Direct Investment

CBAO: Central bank of West African States

GDP: Gross Domestic Product

HP filter: Hodrick-Prescott filter

OECD countries: Organization for Economic Cooperation and Development member countries.

WAEMU: West African Economic and Monetary Union 


\section{Appendix}

Table 1. Estimation Results

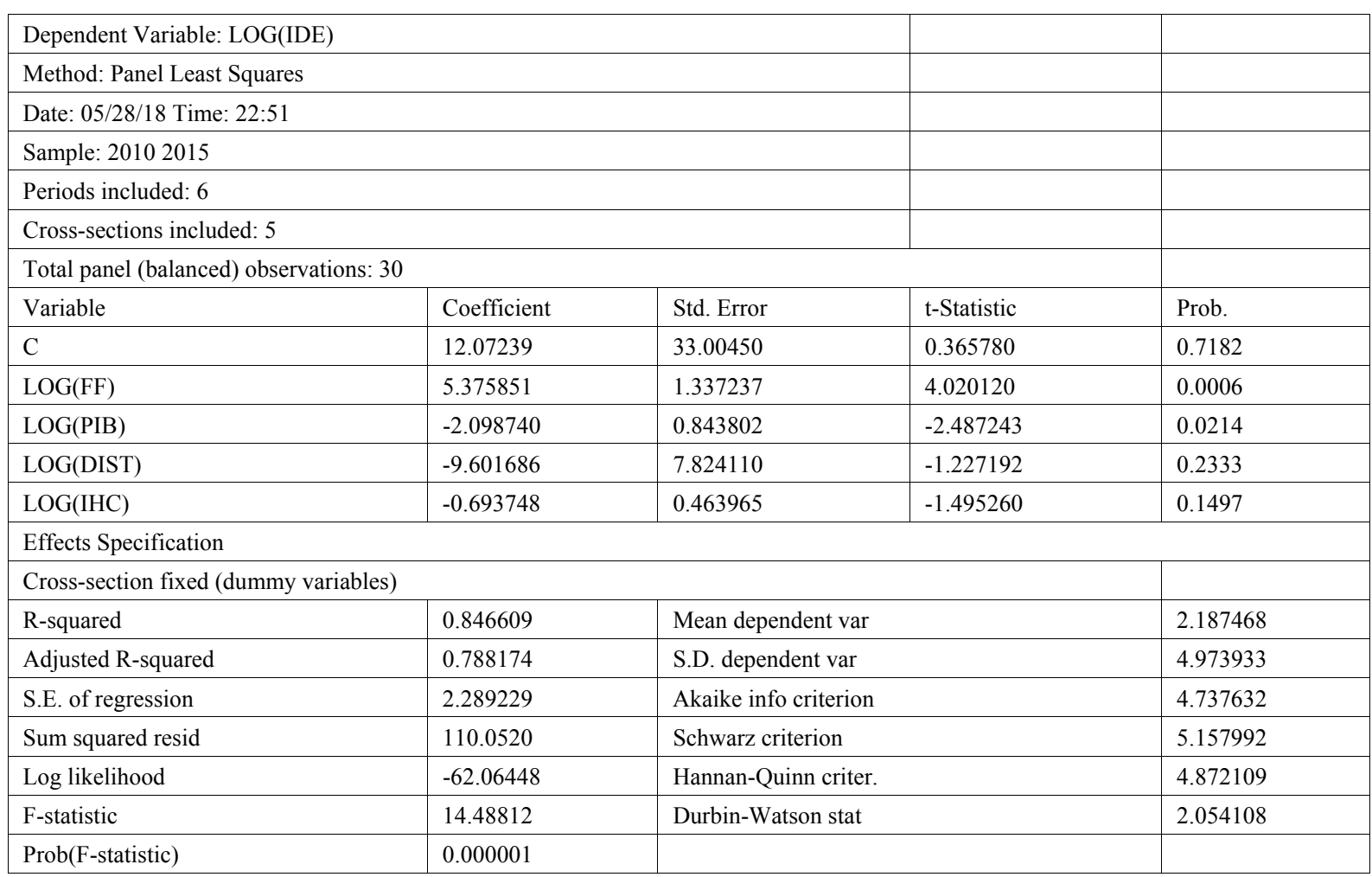

Table 2. Homogeneity test

\begin{tabular}{|c|c|c|c|c|}
\hline \multicolumn{3}{|c|}{ Dependent Variable: LOG(IDE) } & & \\
\hline \multicolumn{5}{|c|}{ Method: Panel Least Squares } \\
\hline \multicolumn{5}{|c|}{ Date: 05/28/18 Time: $22: 39$} \\
\hline \multicolumn{5}{|l|}{ Sample: 20102015} \\
\hline \multicolumn{5}{|l|}{ Periods included: 6} \\
\hline \multicolumn{5}{|c|}{ Cross-sections included: 5} \\
\hline \multicolumn{5}{|c|}{ Total panel (balanced) observations: 30} \\
\hline Variable & Coefficient & Std. Error & t-Statistic & Prob. \\
\hline $\mathrm{C}$ & 12.07239 & 33.00450 & 0.365780 & 0.7182 \\
\hline LOG(FF) & 5.375851 & 1.337237 & 4.020120 & 0.0006 \\
\hline LOG(GDP) & -2.098740 & 0.843802 & -2.487243 & 0.0214 \\
\hline LOG(DIST) & -9.601686 & 7.824110 & -1.227192 & 0.2333 \\
\hline LOG(IHC) & -0.693748 & 0.463965 & -1.495260 & 0.1497 \\
\hline \multicolumn{5}{|l|}{ Effects Specification } \\
\hline \multicolumn{5}{|c|}{ Cross-section fixed (dummy variables) } \\
\hline R-squared & 0.846609 & Mean dependent var & & 2.187468 \\
\hline Adjusted R-squared & 0.788174 & S.D. dependent var & & 4.973933 \\
\hline S.E. of regression & 2.289229 & Akaike info criterion & & 4.737632 \\
\hline Sum squared resid & 110.0520 & Schwarz criterion & & 5.157992 \\
\hline Log likelihood & -62.06448 & Hannan-Quinn criter. & & 4.872109 \\
\hline F-statistic & 14.48812 & Durbin-Watson stat & & 2.054108 \\
\hline Prob(F-statistic) & 0.000001 & & & \\
\hline
\end{tabular}


Table 3. Fisher Test

\begin{tabular}{|c|c|c|c|}
\hline \multirow{2}{*}{ Homogeneity Tests } & \multicolumn{3}{|c|}{ Estimations } \\
\hline & Fisher Statistics & F-stat & P-value \\
\hline \multirow{2}{*}{ Test 1} & $\mathrm{~F} 1=(\mathrm{SC} \mathrm{R} 1-\mathrm{SC} \mathrm{R}) / \mathrm{N}-1)(\mathrm{k}+1)$ & \multirow{2}{*}{21.91} & \multirow{2}{*}{0.0014} \\
\hline & $\mathrm{SC} \mathrm{R} /(\mathrm{N} \times \mathrm{T}-\mathrm{N}(\mathrm{k}+1))$ & & \\
\hline \multirow{2}{*}{ Test 2} & $\mathrm{~F} 2=(\mathrm{SC} \mathrm{R} \mathrm{c} 2-\mathrm{SC} \mathrm{R}) /((\mathrm{N}-1) \times \mathrm{k})$ & \multirow{2}{*}{4.45} & \multirow{2}{*}{0.053} \\
\hline & $\mathrm{SC} \mathrm{R} /(\mathrm{N} \times \mathrm{T}-\mathrm{N}(\mathrm{k}+1))$ & & \\
\hline \multirow{2}{*}{ Test 3} & $\mathrm{~F} 3=(\mathrm{SC} \mathrm{R} \mathrm{c1}-\mathrm{SC} \mathrm{R} \mathrm{c} 2) /(\mathrm{N}-1)$ & \multirow{2}{*}{25.23} & \multirow{2}{*}{0.00009} \\
\hline & $\mathrm{SC} \mathrm{R} \mathrm{C} 2 /(\mathrm{N} \times(\mathrm{T}-1)-\mathrm{k})$ & & \\
\hline
\end{tabular}

In order to determine the nature of the individual effects (fixed or random). And therefore determine the estimation method

Table 4. Hausman Test

\begin{tabular}{|c|c|c|c|c|}
\hline \multicolumn{4}{|c|}{ Correlated Random Effects - Hausman Test } & \\
\hline \multicolumn{4}{|l|}{ Equation: Untitled } & \\
\hline \multicolumn{4}{|c|}{ Test cross-section random effects } & \\
\hline \multicolumn{2}{|l|}{ Test Summary } & Chi-Sq. Statistic & Chi-Sq. d.f. & Prob. \\
\hline \multicolumn{2}{|l|}{ Cross-section random } & 45.753839 & 4 & 0.0000 \\
\hline \multicolumn{5}{|c|}{ Cross-section random effects test comparisons: } \\
\hline Variable & Fixed & Random & Var(Diff.) & Prob. \\
\hline LOG(FF) & 5.375851 & 6.714524 & 0.993327 & 0.1792 \\
\hline LOG(GDP) & -2.098740 & -2.133811 & 0.038880 & 0.8588 \\
\hline LOG(DIST) & -9.601686 & -9.982500 & 45.573851 & 0.9550 \\
\hline LOG(IHC) & -0.693748 & -0.145930 & 0.021037 & 0.0002 \\
\hline \multicolumn{4}{|c|}{ Cross-section random effects test equation: } & \\
\hline \multicolumn{3}{|c|}{ Dependent Variable: LOG(IDE) } & & \\
\hline \multicolumn{3}{|c|}{ Method: Panel Least Squares } & & \\
\hline \multicolumn{3}{|c|}{ Date: $05 / 28 / 18$ Time: $22: 47$} & & \\
\hline \multicolumn{3}{|l|}{ Sample: 20102015} & & \\
\hline \multicolumn{5}{|l|}{ Periods included: 6} \\
\hline \multicolumn{5}{|c|}{ Cross-sections included: 5} \\
\hline \multicolumn{4}{|c|}{ Total panel (balanced) observations: 30} & \\
\hline Variable & Coefficient & Std. Error & $\mathrm{t}$-Statistic & Prob. \\
\hline $\mathrm{C}$ & 12.07239 & 33.00450 & 0.365780 & 0.7182 \\
\hline LOG(FF) & 5.375851 & 1.337237 & 4.020120 & 0.0006 \\
\hline LOG(GDP) & -2.098740 & 0.843802 & -2.487243 & 0.0214 \\
\hline LOG(DIST) & -9.601686 & 7.824110 & -1.227192 & 0.2333 \\
\hline LOG(IHC) & -0.693748 & 0.463965 & -1.495260 & 0.1497 \\
\hline \multicolumn{5}{|l|}{ Effects Specification } \\
\hline \multicolumn{4}{|c|}{ Cross-section fixed (dummy variables) } & \\
\hline R-squared & 0.846609 & \multicolumn{2}{|l|}{ Mean dependent var } & 2.187468 \\
\hline Adjusted R-squared & 0.788174 & \multicolumn{2}{|l|}{ S.D. dependent var } & 4.973933 \\
\hline S.E. of regression & 2.289229 & \multicolumn{2}{|l|}{ Akaike info criterion } & 4.737632 \\
\hline Sum squared resid & 110.0520 & \multicolumn{2}{|l|}{ Schwarz criterion } & 5.157992 \\
\hline Log likelihood & -62.06448 & \multicolumn{2}{|l|}{ Hannan-Quinn criter. } & 4.872109 \\
\hline F-statistic & 14.48812 & \multicolumn{2}{|l|}{ Durbin-Watson stat } & 2.054108 \\
\hline Prob(F-statistic) & 0.000001 & & & \\
\hline
\end{tabular}




\section{REFERENCES}

[1] Alfaro, L., S. Kalemli-Ozcan, A. Chanda, and S. Sayek (2010). Does Foreign Direct Investment Promote Growth? Exploring the Role of Financial Markets on Linkages, Journal of Development Economics 91(2), pp 242-256.

[2] Steven Poelhekke (2014). Do global banks facilitate foreign direct investment? VU University Amsterdam and De Nederlandsche Bank (Dutch Central Bank).

[3] Goldberg, L.S. (2009). Understanding Banking Sector Globalization, IMF Staff Papers 56, 171-197.

[4] Klein, M.W., J. Peek and E.S. Rosengren (2002). Troubled Banks, Impaired Foreign Direct Investment: The Role of Relative Access to Credit, American Economic Review 92(3), 664-682.

[5] J.Métais (1979) «Le processus de multinationalisation des grandes banques commerciales». Revue économique, volume $30, n^{\circ} 3$. pp. 487-517.

[6] Jan. TINBERGEN, «An analysis of world trade flows», Shaping the World Economy, 1962.

[7] M.Frenkel, K.Funke and G.Stadmann (2004) A panel analysis of bilateral FDI flows to emerging economies, Economic Systems, vol. 28, issue 3, 281-300.

[8] RAPPORT ANNUEL DE LA COMMISSION BANCAIRE DE L'UEMOA 2010.

[9] RAPPORT ANNUEL DE LA COMMISSION BANCAIRE DE L'UEMOA 2011.

[10] RAPPORT ANNUEL DE LA COMMISSION BANCAIRE DE L'UEMOA 2012.

[11] RAPPORT ANNUEL DE LA COMMISSION BANCAIRE DE L'UEMOA 2013.

[12] RAPPORT ANNUEL DE LA COMMISSION BANCAIRE DE L'UEMOA 2014.

[13] RAPPORT ANNUEL DE LA COMMISSION BANCAIRE DE L'UEMOA 2015. 